\title{
Does Origin Matter? Ethnic Group Position and Attitudes Toward Immigrants: The Case of Russia
}

\author{
Zuzanna Brunarska ${ }^{1,2}$ and Wiktor Soral ${ }^{2,3}$ \\ ${ }^{1}$ Centre of Migration Research, University of Warsaw, Poland, ${ }^{2}$ The Robert B. Zajonc Institute for Social Studies, University of \\ Warsaw, Poland and ${ }^{3}$ Faculty of Psychology, University of Warsaw, Poland \\ Corresponding author: Zuzanna Brunarska, email: zuzanna.brunarska@uw.edu.pl
}

\begin{abstract}
This article analyzes the relationship between the relative position of an ethnic group, as measured by its majority/minority status at a subnational level, and attitudes of its members toward immigrants of different origins. Based on the Russian case, it addresses the question whether the effects of in-group majority status within a region on attitudes toward the general category of immigrants hold regardless of out-group origin and, if not, what may drive this variation. Using data from the Russia Longitudinal Monitoring Survey of the Higher School of Economics and Bayesian hierarchical structural equation modeling, the study demonstrates that the relative position of an ethnic in-group is of varying importance as a predictor of attitudes toward migrant groups of European versus non-European origin in Russia. A group's majority status within a region proved to play a role in predicting attitudes toward migrants originating from the "south" (encompassing North and South Caucasus; Central Asia; and China, Vietnam, and Korea) but not toward migrants coming from the "west" (Ukraine and Moldova). We draw on arguments related to the source and the level of threat induced by the out-groups, ethnic hierarchies, and group cues to explain this pattern of results.
\end{abstract}

Keywords: attitudes toward immigrants; group position; majority status; origin; Russia

Given the prevalence of migration processes and integration challenges faced by various receiving societies in today's world, attitudes toward newcomers have become an increasingly topical issue. Public opinion polls often measure attitudes toward a broad category of immigrants. Meanwhile, it has been shown that mental images of immigrants vary across individuals, and people usually do not generalize their answers across different subcategories-for example, representing different origins-but rather tend to concentrate on specific subcategories (Blinder 2015). Even when a survey asks about various subcategories of immigrants, attitudes toward immigrant targets have often been analyzed jointly in academic research (Ford 2011; Ruedin 2020). The implicit assumption underlying such an approach is that the same theoretical mechanisms work in the cases of all immigrant groups. This might not necessarily be true, as shown by the recently growing body of research that acknowledges the existence of differences in the attitudes toward different immigrant groups and in the mechanisms underlying them (Brader, Valentino, and Suhay 2008; Ford 2011; Ford and Mellon 2020; Gorodzeisky and Semyonov 2019; Hainmueller and Hopkins 2015; Harell et al. 2012; Konitzer et al. 2019; Raijman, Hochman, Davidov 2021; Ruedin 2020; Tartakovsky and Walsh 2020; Timberlake et al. 2015; Turper et al. 2015; Valentino, Brader, and Jardina 2013). We contribute to this line of research by testing the assumption of common theoretical mechanisms for

\footnotetext{
(C) The Author(s), 2022. Published by Cambridge University Press on behalf of Association for the Study of Nationalities. This is an Open Access article, distributed under the terms of the Creative Commons Attribution licence (https://creativecommons.org/licenses/by/4.0/), which permits unrestricted re-use, distribution, and reproduction in any medium, provided the original work is properly cited.
} 
a model explaining anti-immigrant attitudes with the relative position of an ethnic in-group for different immigrant origins in Russia.

The argument that perceived in-group position is important in explaining negative attitudes toward out-groups was raised over 60 years ago (Blumer 1958). In his original group position model, Blumer named four inherent elements underlying race prejudice: a sense of superiority regarding one's own group, a belief in its distinctiveness from other groups, a feeling of entitlement to certain advantages and institutionalized privileges, and perceived competitive threat. The perception of an in-group position may stem from an in-group's majority or minority status in terms of its relative size compared to other ethnic groups inhabiting a particular territory.

However, in multiethnic societies, several complexities may arise, which justify extending Blumer's original model. In such societies, ethnic composition of the population may differ across regions, and it is possible that an ethnic group constituting a majority at a country level does not possess a majority status within some of the country's subdivisions. In this vein, the Russian Federation, with its multiethnic society, offers an interesting, yet still largely understudied, setting for analyzing attitudes toward immigrants. It is a suitable site for examining the role of relative group position at a subnational level in shaping attitudes toward immigrants, since it contains several regions in which ethnic groups other than the country-level dominant group (ethnic Russians) hold a majority status. Consequently, it allows examination of the potential consequences of positionality that may be overlooked in a typical nation-state context.

Previous research suggested that the attitudes toward immigrants among majority ethnic group and among members of minority ethnic groups in Russia are driven by different mechanisms with regard to the position of an in-group. At the national level, they to a varying degree rely on perceptions of collective interests and vulnerabilities, with attitudes of ethnic Russians to a greater extent dependent on the group position-related factors (Gorodzeisky and Glikman 2018). At the subnational level, in turn, they proved to be differently related to the in-group position. While a majority status at a regional level held by ethnic Russians seems to promote anti-immigrant attitudes (Brunarska 2019; cf. Hraba et al. 1997), in the case of members of titular ethnic groups, majority status at a regional level seems to inhibit exclusionist attitudes toward immigrants (Brunarska 2019; cf. Alexseev 2010; Minescu and Poppe 2011 for interethnic relations). Brunarska (2019) explains this pattern of results with reference to two theoretical perspectives: social dominance theory (Pratto et al. 1994) and the group position model (Bobo and Hutchings 1996). The former posits that members of high-status groups show greater out-group prejudice than members of low-status groups due to higher levels of social dominance orientation, which may explain the operation of group position in the case of ethnic Russians. The latter posits that groups in the subordinate position experience a feeling of racial alienation, which makes them more likely to perceive out-group members as competitors for scarce resources. It is argued that the feeling of alienation experienced by titulars, due to their subordinate position at the national level, is alleviated when they hold a majority status within a region. These relationships have not been, however, tested across different migrant groups. We assumed that accounting for the heterogeneity of immigrants in terms of their origin would allow for a more informed consideration of the mechanisms shaping attitudes toward them.

Perceived competitive threat constitutes a core mechanism explaining exclusionary attitudes toward out-groups in the literature on attitudes toward immigrants (Raijman, Hochman, and Davidov 2021; Ruedin 2020; Schoon and Anderson 2017). Given that it is one of the four inherent elements underlying prejudice according to Blumer's group position model, we also make it a key element of our theoretical framework and, as a result, of our considerations. Since immigrants coming from different origins challenge various interests of receiving communities, and different migrant groups may consequently activate different types (Hellwig and Sinno 2017; Meuleman et al. 2018) and levels of threat (cf. Bloom, Arikan, and Lahav 2015), the question arises as to whether the relationship between in-group's majority status within a region and attitudes toward the general category of immigrants holds regardless of out-group origin. In broader terms, we ask whether the 
effects of the relative position of an ethnic in-group on attitudes toward immigrants vary between origins and, if so, what may drive this variation. In our approach, we thus follow Timberlake et al. (2015), who sought to determine whether the link between immigrant stereotypes and perceived impact of immigration depends on the immigrant group under consideration. We presume that a group position may be differentially important as a predictor of attitudes toward different migrant groups. We formulate more specific research hypotheses further in the paper.

\section{Generalized Prejudice versus Differentiated Threat Approach}

According to the generalized prejudice approach (Bergh and Akrami 2016), sometimes also referred to in the literature as group-focused enmity (Zick et al. 2008), attitudes toward different sorts of out-groups share a common core. In other words, this approach expects that some people score high in prejudice against multiple target groups. However, by generalizing attitudes across target groups, the perspective of generalized prejudice disregards the social context of specific interethnic relations, in particular the out-group-specific contexts. The differentiated threat approach (Meuleman et al. 2018), in turn, accounts for ethnic contexts in which intergroup relations are embedded. As Meuleman et al. state, this approach concentrates on "how the positionality of the different others to the ingroup may invoke differentiated othering mechanisms" $(2018,239)$. According to this theoretical perspective, specific prejudices depend on the source of threat a particular out-group triggers. ${ }^{1}$ Sources of out-group threat are usually divided in the literature into two main types-realistic and symbolic (according to the revised integrated threat theory; Stephan, Ybarra, and Morrison 2009), sometimes also framed as material versus cultural threats (Bloom, Arikan, and Lahav 2015). The former relates to political and economic power, resources, general welfare, and physical and material well-being, that is, "the very existence of the ingroup" (Stephan et al. 2009, 43). The latter relates to the in-group's cultural or religious values, beliefs, morality, and worldview, that is, the in-group's "way of life." In line with the differentiated threat approach, migrants coming from different places of origin "challenge diverse realistic and symbolic interests" (Meuleman et al. 2018, 222) and therefore they are not perceived uniformly by the receiving society.

We expect that not only may different groups trigger different types and levels of threat, which influences attitudes toward them, but also that different theory-based mechanisms, assuming threat as an underlying factor, may or may not work for different groups. Regarding the role of group position, in line with the generalized prejudice approach, one would assume that the relative position of an ethnic in-group should have a similar effect on attitudes regardless of the target group. In contrast, the differentiated threat perspective would entail that group position may have a divergent effect depending on the object. Consequently, in line with both approaches combined, we hypothesize that one may note divergent effects of group position for the clusters combining immigrant target groups associated with different types of threat. A stronger claim may be derived from the study by Minescu and Poppe (2011), who noted that the effect of in-group size on perceived interethnic conflict is amplified by higher levels of perceived cultural threat and out-group encroachment (growing out-group influence). As they argued, perceived threat and out-group encroachment act as "levers or switches that conditioned the effects of group entitlement in fueling conflict perceptions" (185). This leads us to expect the effect of relative in-group size, as expressed by majority status, to be smaller in the case of migrant out-groups whose presence is less often associated with symbolic threat and encroachment. Unfortunately, due to the limitations of our data, which do not allow operationalization of perceived threat triggered by separate origins, we will not be able to provide direct evidence for the operation of the threat mechanism. We thus, similarly to Timberlake et al. (2015), explain why we believe this mechanism is plausible and discuss potential alternative explanations for the patterns observed in our data. 


\section{The Russian Context}

Russia offers a well-suited setting for testing the relevance of in-group position at a regional level across different migrant origins as both a multiethnic society, in which some national minority ethnic groups hold a majority status in the regions they inhabit, and one of the world's largest migrant-receiving states that attracts migrants of different origin. According to the official statistics, immigrants from the former Soviet republics amount to around $90 \%$ of all incoming migrants in Russia. Other important origins include China, India, Vietnam, and North Korea. Previous studies showed that despite the official Soviet ideology promoting the existence of a common Soviet identity, post-Soviet migrants are not perceived homogeneously by the Russian society (Bessudnov and Shcherbak 2020; Gudkov 2005; Levada 2018; Pipiia 2017; Popova and Osipova 2013; see also Gerber and Zavisca 2020). It has also been shown that in-group members tend to arrange ethnic groups in a consensual ethnic hierarchy of social distance, based on the evaluation of cultural rather than socioeconomic differences or economic competition (Bessudnov 2016; Hagendoorn 1995; Hagendoorn et al. 1998). This hierarchy reflects the political dominance of highly positioned Russians and other Slavic peoples (Ukrainians, Belarusians), while the Caucasian and Central Asian minority groups have belonged to systematically rejected out-groups (Bessudnov 2016; Hagendoorn et al. 1998; Popova and Osipova 2013). Importantly, internal migrants representing the titular nations of the North Caucasus republics, despite being Russian citizens, become targets of hostile attitudes throughout other Russian regions (Laruelle 2010; Bessudnov 2016; Grigoryan 2016; Markowitz and Peshkova 2016). This is because a decisive factor shaping xenophobia in Russia is ethnic belonging, not citizenship or country of origin (Popova and Osipova 2013). Warmer feelings toward newcomers of Slavic ethnicity suggest that devaluation of North Caucasian and Central Asian immigrant groups is based on a symbolic (cultural) rather than on a realistic (socioeconomic) threat. Interestingly, immigrants from countries of the South Caucasus, despite their cultural heterogeneity, are usually placed in one group with the North Caucasian and Central Asian migrants (Grigor'ev 2017; Pipiia 2017; Butkovich Kraus and Herrera 2010; Gerber 2014), which may be because religion is not a decisive factor shaping ethnic hierarchies in Russia either (Bessudnov and Shcherbak 2020).

Despite the results of survey research showing that attitudes toward different ethnic or migrant groups vary in Russia, previous theory-driven studies have often limited their considerations to attitudes toward a general category of immigrants, not distinguishing between different target groups (Alexseev 2010, 2011; Bahry 2016; Brunarska 2019; Gorodzeisky, Glikman, and Maskileyson 2015; Grigoryan 2016). A notable exception is the study by Bessudnov (2016), who noted that theory-driven associations between attitudes toward immigrants and their predictors (immigrant concentration in his case) are present only for immigrants from the Caucasus and Central, East, and Southeast Asia, while they do not prove significant for migrants of Ukrainian and Moldovan origin. Although he focused on a different research problem than the one handled in this paper, his observation provides evidence that attitudes toward the two clusters of migrant groups are qualitatively different. Another noteworthy exception is the study by Gorodzeisky (2019), who, based on European Social Survey data, differentiated between exclusionary attitudes based on national membership (directed at all foreigners regardless of their origin) and exclusionary attitudes based on race or ethnicity (directed solely at racially or ethnically different foreigners). She studied, among other things, the role of perceived collective (state) vulnerability in predicting exclusionary attitudes and concluded that it prompts exclusionary attitudes toward all foreigners. While differentiation between target groups is not common in theory-driven studies that focus on attitudes toward migrants in Russia, it is more common in theory-driven empirical research focused on attitudes toward members of ethnic out-groups, without an emphasis on their migration background (Butkovich Kraus and Herrera 2010; Gerber 2014; Hagendoorn et al. 1998; Herrera and Butkovich Kraus 2016; Hraba et al. 1997). Although the out-groups considered differed across studies, which led researchers to adopt various names to label their groupings, taken together, 
previous research pointed to the existence of a fundamental divide between how Russian society views groups of European, western origin as opposed to non-European, southern origin. For instance, Bessudnov and Shcherbak (2020) differentiated between ethnic groups of European (Germans, Jews, Latvians, Lithuanians, ethnic Russians, and Ukrainians) and non-European (Armenians, Azerbaijanis, Chechens, Georgians, Tajiks, Uzbeks, and Tatars) origin. Gerber (2014) distinguished views toward western (Americans, Jews, Swedes) and southern groups (Azerbaijanis, Chechens, Gypsies, Muslims, Tajiks). Butkovich Kraus and Herrera (2010) made a distinction between a Western (Jews, Americans, Italians, Swedes, and Catholics) and an Eastern/ Southern (Chechens, Azeris, Roma, and Muslims) factor within xenophobic attitudes. While we acknowledge that there might be further distinctions within these broad categories (Gerber and Zavisca 2020), we hypothesize that this divide between the two clusters of migrant groups is also relevant when the focus is on the role of group position in determining attitudes toward newcomers. Namely, we expect to observe that attitudes toward immigrant groups of non-European, southern immigration origin are reliably related to the in-group position, whereas attitudes toward groups of European, western immigration origin will be unaffected by the in-group position.

\section{Method}

\section{Data}

The study utilized data derived from the 17th round of the Russia Longitudinal Monitoring Survey of the Higher School of Economics (RLMS-HSE 2008), which included several questions concerning immigrants and respondents' attitudes toward them. Although this round was conducted over 10 years ago (between October 2008 and January 2009), data related to the portion of questions on immigrants were not released for public use until 2016 and have not been used much so far. The survey covered 38 primary sampling units (PSUs), which included cities, towns, and rural areas that lie within 32 federal subjects of Russia, including 19 oblasts, five republics, six krais, and two federal cities: Moscow and St. Petersburg. The original sample size amounted to 9,874 individuals. The current study concentrates on adults $(\mathrm{N}=8,094)$, excluding individuals aged under 18 from the analysis. Importantly, in each household an attempt was made to interview all its members. Consequently, the RLMS-HSE data have a three-level structure, with individuals nested in households and households clustered in regions (PSUs).

While the RLMS-HSE is regarded as offering data of exceptionally high quality, it has certain limitations when the focus is on the population's ethnic structure. This stems from the fact that it covers only five (out of 21) ethnic republics of Russia and is not representative at the federal subject level. The republics encompassed by the survey included the Komi Republic, Chuvashia, Tatarstan, Kabardino-Balkaria, and Udmurtia. Consequently, representatives of non-Russian ethnic groups in the sample are mostly composed of members of titular ethnic groups of these five regions. This is also reflected in the structure of the two ethnically non-Russian groups we seek to compare in our study: majority and minority titulars. The former included Tatars, Chuvashes, and Kabardins in their ethnic republics (in three locations: Kazan, Shumerlia and Shumerlinskii raion, and Zalukokoazhe and Zol'skii raion). The latter included primarily Udmurts (mostly in Glazov and Glazovskii raion in Udmurtia), Komis (resident in Syktyvkar, and Usinsk and Usinskii raion in the Komi Republic), Balkars (living in Zalukokoazhe and Zol'skii raion in Kabardino-Balkaria), Tatars outside of Tatarstan, Chuvashes outside of Chuvashia, and Mordvinians and Bashkirs. Comparison of ethnic Russians in minority and majority position at a regional level, in turn, boils down to comparing attitudes of ethnic Russians living in Kazan (Tatarstan), Shumerlia and Shumerlinskii raion (Chuvashia), and Zalukokoazhe and Zol'skii raion (Kabardino-Balkaria) to attitudes of those residing in the remaining 35 PSUs located in the 29 federal subjects of Russia covered by the RLMSHSE sample. As a result, generalizability of the study findings to other ethnic groups and localities/ regions in Russia should not be taken for granted. 


\section{Measures}

\section{Attitudes toward Immigrants}

Attitudes toward immigrants were measured by a question about how a respondent would react to a hypothetical situation in which an ordinary migrant family originating from a specific place (country or region) had settled next door. This question was repeated for six different origins: Ukraine; Moldova; the North Caucasus (a family of Dagestanis, Chechens, Cherkesses, and others); South Caucasus (Azerbaijanis, Armenians, Georgians); Central Asia (Kyrgyz people, Uzbeks, Tajiks, or others); and China, Vietnam, and Korea, forming one category. ${ }^{2}$ The answers for each origin were scored on a five-point Likert scale, where one represented a positive attitude and five corresponded to a negative attitude. While such an operationalization constitutes an example of an item typically used to measure social distance (Bogardus 1925), its focus on the question of neighbors means that attitudes measured this way are more likely to be driven by symbolic rather than by realistic threat (cf. Velasco González et al. 2008). To conduct the analyses regarding differential predictive values of in-group position for the two clusters of migrant origins, we aggregated (averaged) attitudes toward immigrants of different origins into two sets consisting of western, European immigrant groups (from Ukraine or Moldova) and southern immigrant groups (from the Caucasus and Central, East or Southeast Asia).

\section{Position of an Ethnic In-Group}

The relative position of an ethnic in-group was expressed in terms of a respondent's ethnic group status within a given federal subject-majority versus minority (where holding a majority status means being the most numerous ethnic group in a given territorial unit, according to the 2010 Russian population census [Rosstat 2013]). Importantly, respondents were asked about their selfdeclared ethnic identity and were allowed to report any identity, including a mixed one. To account for the divergent effect of group position for ethnic Russians and members of minority ethnic groups, we differentiated between the following five categories: majority Russians, minority Russians, majority titulars, minority titulars, and others. ${ }^{3}$ We separated titulars from others because we view the two national minority subgroups as qualitatively different-we assumed that by being in a minority position in a region, titulars, as members of an autochthonous group with a potentially greater sense of group entitlement (Martinovic and Verkuyten 2013), may experience a stronger feeling of alienation than members of non-titular ethnic minority groups. Moreover, the others category, which primarily includes people of Ukrainian, Armenian, Belarusian, German, Azerbaijani, Kazakh, Moldovan, and Georgian ethnicity, has been more heavily replenished by immigrants, and consequently its members may show more positive attitudes toward potential migrant neighbors than representatives of more sedentary ethnic groups (see Bessudnov 2016). While it might be informative to disaggregate specific titular groups, we need to combine them to increase the statistical power of our analysis. We used a five-category notation instead of a classic $2 \times 3$ interaction because the others category consists of ethnicities that do not form a majority within any federal subject of Russia (which would otherwise lead to an empty category). While we fitted the model to data that included the others category, we conducted hypothesis tests focused only on ethnic Russians and titulars, as we were primarily interested in the interaction of respondent's ethnicity (Russian vs. titular) and group position. We estimated this interaction after fitting the model with a linear hypothesis testing approach (by computing a contrast representing this interaction).

\section{Control Variables}

Covariates included respondents' gender, age, education level, household's per capita logtransformed income, migration status, and locality type. Migration status was captured by a dummy variable stating whether a respondent was born in Russia (or Russian SFSR) or beyond its borders. For basic descriptive statistics of variables used in the analysis, see table A1 in the appendix. 


\section{Statistical Analysis}

We used Bayesian ${ }^{4}$ hierarchical structural equation modeling (BHSEM) to examine the relationship between group position and attitudes toward immigrants. The model took the form of a system of two regression equations in which respondents' $(\mathrm{N}=8,094)$ attitudes toward immigrants of western and southern origins were regressed on other variables. It included both fixed and random effects. The latter involved varying intercepts both at the level of regions (PSUs, $\mathrm{N}=38)$ and households $(\mathrm{N}=3,808)$ within regions, thus forming a three-level nested structure. Each response variable was treated as an interval measure, and hence the respective equations took a Gaussian form. We chose to use weakly informative prior distributions for all the parameters (e.g., Gelman et al. 2008). Graphical posterior predictive checks (Gabry et al. 2019) indicated moderate albeit acceptable differences between predicted and observed values of the response variables. We tested models with both correlated and noncorrelated residuals of the response variables.

To adjust for the unequal sampling probabilities, we used sampling weights both at the level of households and individuals. Following recommendations for fitting multilevel models with complex survey data, we scaled individual level weights (using Method B [Carle 2009]). To account for missing values (across the variables used in the analyses the proportion of missing data ranged from $0 \%$ to $6.6 \%$ ), we conducted multiple imputation (with the R-package mice [van Buuren and Groothuis-Oudshoorn 2011]) and ran the model simultaneously on five imputed datasets. The imputation model included all the variables used in the regression models (see the suggestion by Enders [2010]).

The models were fitted with the brms R package (Bürkner 2017), using 2 MCMC (Markov Chain Monte Carlo) chains per imputed dataset, resulting in 10 chains in total. Values of the potential scale reduction factor were lower than 1.02, indicating no problems with the chains' convergence.

\section{Results}

A look at the general descriptive statistics, showing average attitudes toward potential migrant neighbors of different origins in Russia (see table A1), indicates that migrants of Ukrainian and Moldovan origin are more welcome than migrants coming from all the other regions and countries considered (i.e., the North and South Caucasus, Central Asia, and China, Vietnam, and Korea). An average score for potential migrant neighbors coming from Ukraine and Moldova was 2.75 and 2.89 , respectively, which means that they are generally perceived more positively than negatively by the receiving society (given that three stands for a neutral attitude). Immigrants originating from the remaining four regions are, in turn, perceived rather negatively on average (and similarly to one another, with averages ranging from 3.52 to 3.65).

We are interested in whether the differences between the two clusters of migrant groups-that we labelled as western and southern target out-groups-are visible when one considers the role of in-group position in the ethnically stratified social order-namely, its majority or minority status at a regional level. Figure 1 illustrates the role of majority status for ethnic Russians and members of titular ethnic groups, respectively.

It shows that the role of the relative position of an ethnic in-group differs across migrant outgroups of different origin. Both for ethnic Russians and for members of titular nations, the majority status in a region seems to play a role in predicting attitudes toward migrant groups of Caucasian, Central Asian, and East and Southeast Asian origin. As for the Ukrainian and Moldovan target groups, the evidence proves to be "negative" in the case of ethnic Russians, while it might be described as "substantial" or "very strong," respectively, but not "decisive," in the case of titulars (cf. Jeffreys 1961, 432). It also demonstrates that in the case of migrants originating from the "south," majority status at a regional level translates into more negative attitudes among ethnic Russians and more positive attitudes among representatives of titular ethnic groups. 
Status of ethnic ingroup: $\square$ majority $\square$ minority
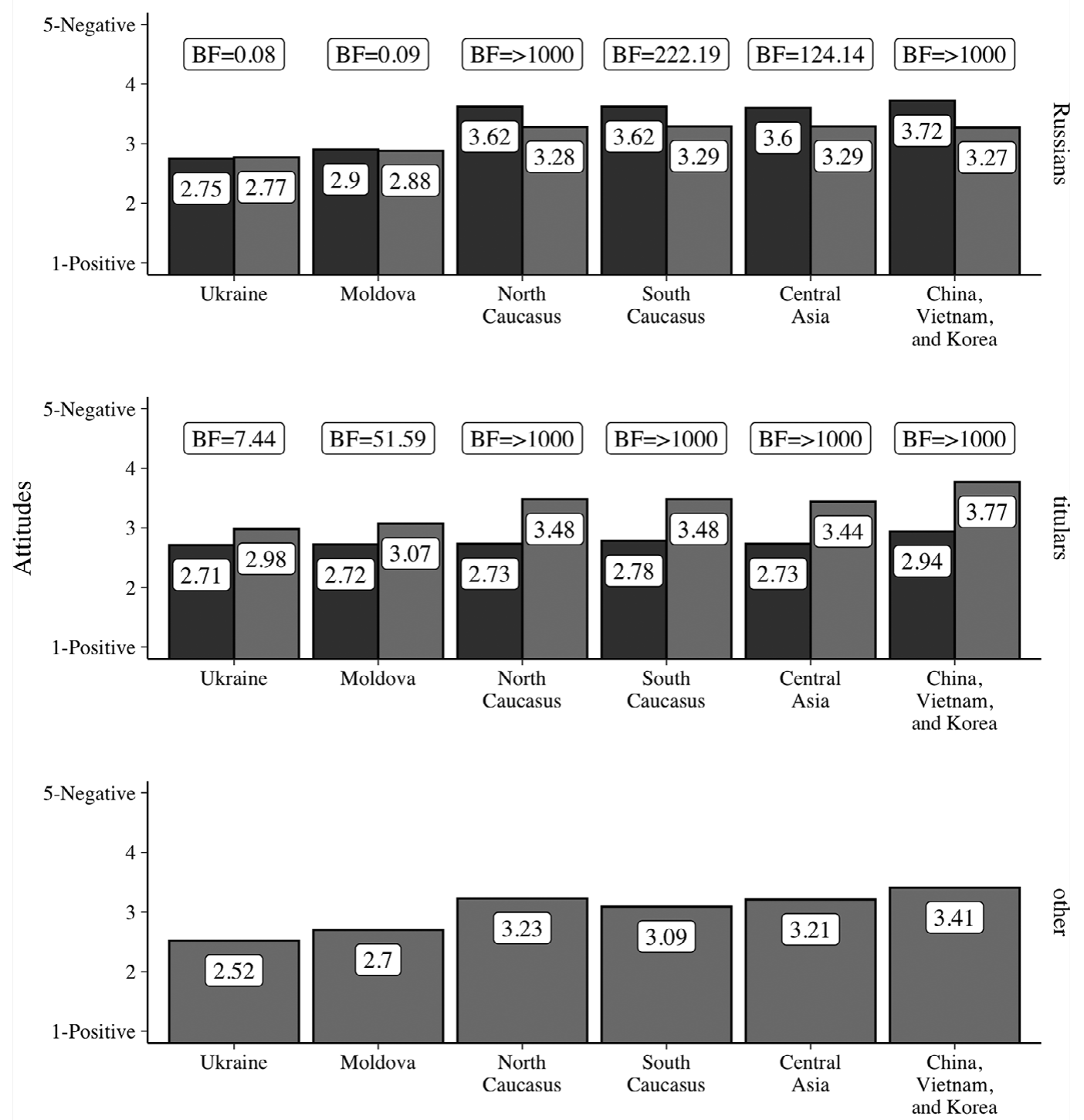

Target of attitudes

Figure 1. Average Attitudes (Y-Axis) toward Different Target Groups (X-Axis) Reported by Ethnic Russians, Titulars, and Others (See the Label on the Right Side of the Facet) Depending on Their Majority or Minority Status (See Different Shades of Grey). Note. BF refers to Bayes Factor in support of the hypothesis that differences between majority and minority groups are not 0 .

We then tested the differences in attitudes toward the two broad origins-western and southern groups-between majority and minority in-groups, both among ethnic Russians and titulars. To ensure that the observed differences regarding the effects of group position and ethnicity on attitudes toward immigrants of western and southern origin are not attributed to structural characteristics unrelated to group position, we used a hierarchical model adjusting for a number of additional sociodemographic variables (see figure 2 for estimated marginal means). ${ }^{5}$ Table 1 presents a summary of estimates along with highest posterior density intervals (HPDI) as a measure of their uncertainty. The model explained around $40 \%$ of the variance of the response variables. We 


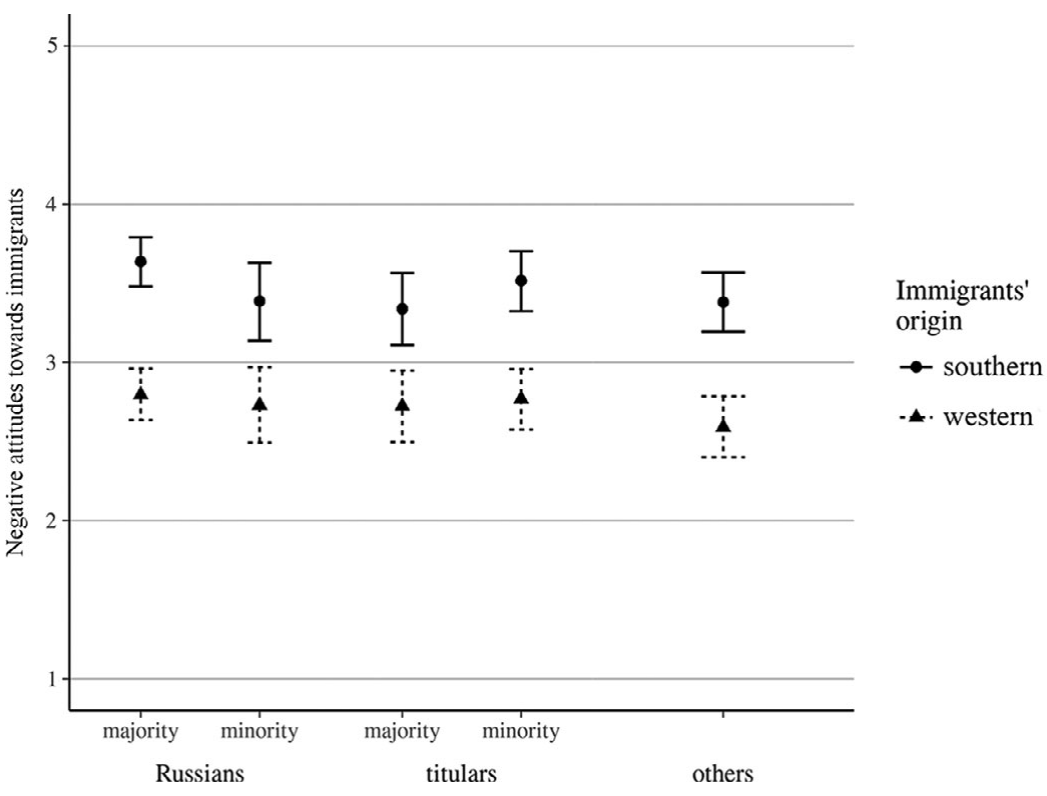

Figure 2. Estimated Marginal Means of Attitudes toward Immigrants of Southern and Western Origin across Russians, Titulars (Both Constituting either Majority or Minority), and Others.

chose the model with correlated residuals because it obtained better out-of-sample predictive accuracy measures than a model with noncorrelated residuals (WAIC $=37,694.45$ vs. WAIC $=$ 40,451.65, respectively).

In the case of attitudes toward immigrants of western, European origin, the contrast describing interaction between a respondent's ethnicity (Russian vs. titular) and in-group status was not credible (the interaction contrast was small and close to $0, \psi=0.10,95 \%$ HPDI $[-0.07,0.27]$ ). Furthermore, there were no credible differences between majority and minority groups, neither among ethnic Russians (difference, $\psi=0.13,95 \%$ HPDI $[-0.07,0.32]$, $\mathrm{d}_{\text {Cohen }}=0.14$ ) nor among titulars (difference, $\psi=-0.07,95 \%$ HPDI $[-0.28,0.13]$, $\mathrm{d}_{\text {Cohen }}=-0.06$ ).

In the case of attitudes toward immigrants of southern origin, the ethnicity (Russian vs. titular) and in-group status (majority vs. minority) of respondents formed a credible interactive pattern (as indicated by a large magnitude of interaction contrast, $\psi=0.26,95 \%$ HPDI $[0.09,0.43]$ ). Among ethnic Russians, those holding a majority status in a region showed on average credibly more negative attitudes toward immigrants than those holding minority status at a regional level (difference, $\psi=0.28$, 95\% HPDI $[0.08,0.46], \mathrm{d}_{\text {Cohen }}=0.30$ ). On the contrary, among titulars, those holding a majority status in a region had on average a credibly lower level of anti-immigrant attitudes than titulars holding a minority status in their region of residence (difference, $\psi=-0.24$, 95\% HPDI [-0.47, -0.03], $\left.\mathrm{d}_{\text {Cohen }}=-0.20\right){ }^{6}$

Thus, the results show that the role of the relative position of an ethnic in-group differs across migrant out-groups of different origin. Both for ethnic Russians and for members of titular nations, the majority status seems to play a role in predicting attitudes toward migrant groups of southern origin but not western origin. Moreover, in the case of migrants originating from the "south," the findings confirm the presence of a positive relationship between an in-group's majority status at a regional level and anti-immigrant attitudes in the case of ethnic Russians, while a negative relationship is apparent in the case of members of titular nationalities, which is in line with previous studies. ${ }^{7}$ One should note, however, that the largest observed difference, according to a crude effect size measure, $\mathrm{d}_{\text {Cohen }}=0.30$, should rather be considered as a small effect. This suggests a high degree of variability of the effect and possible influences of other, unobserved factors. 
Table 1. Summary of Posterior Draws from the Hierarchical Structural Equation Model of Negative Attitudes towards Western and Southern Immigrant Groups, with Correlated Residuals

\begin{tabular}{|c|c|c|c|c|}
\hline & \multicolumn{2}{|c|}{ western groups } & \multicolumn{2}{|c|}{ southern groups } \\
\hline & Estimates & HPDI (95\%) & Estimates & HPDI (95\%) \\
\hline intercept & 3.210 & $2.877-3.543^{\star}$ & 3.991 & $3.663-4.331^{*}$ \\
\hline male $($ female $=0$, male $=1)$ & 0.083 & $0.048-0.119^{\star}$ & 0.002 & $-0.033-0.039$ \\
\hline age & -0.003 & $-0.004--0.002^{*}$ & -0.003 & $-0.004--0.002^{*}$ \\
\hline years of education & -0.006 & $-0.013-0.001$ & -0.000 & $-0.007-0.006$ \\
\hline log income & -0.021 & $-0.051-0.009$ & -0.025 & $-0.057-0.006$ \\
\hline born abroad $(n o=0$, yes $=1)$ & -0.092 & $-0.167--0.012^{\star}$ & -0.075 & $-0.153-0.005$ \\
\hline \multicolumn{5}{|l|}{ locality (federal center=0) } \\
\hline$($ town $=1)$ & -0.030 & $-0.251-0.205$ & 0.052 & $-0.149-0.258$ \\
\hline (urban-type=1) & -0.378 & $-0.619--0.132^{\star}$ & -0.485 & $-0.715--0.271^{\star}$ \\
\hline (village $=1)$ & -0.009 & $-0.235-0.221$ & -0.073 & $-0.275-0.128$ \\
\hline \multicolumn{5}{|l|}{ group status/ethnicity (majority Russians=0) } \\
\hline (majority titulars $=1$ ) & -0.103 & $-0.301-0.077$ & -0.351 & $-0.553--0.145^{\star}$ \\
\hline (minority Russians $=1$ ) & -0.126 & $-0.322-0.073$ & -0.281 & $-0.462--0.085^{\star}$ \\
\hline (minority titulars $=1$ ) & -0.037 & $-0.146-0.073$ & -0.114 & $-0.242-0.004$ \\
\hline (others $=1$ ) & -0.211 & $-0.321--0.107^{\star}$ & -0.259 & $-0.369--0.156^{\star}$ \\
\hline \multicolumn{5}{|l|}{ Random Effects } \\
\hline$\varphi^{2}$ & 0.73 & & 0.74 & \\
\hline$\rho_{\text {south/west }}$ & 0.56 & & & \\
\hline \multirow[t]{2}{*}{$\tau_{00}$} & 0.32 region & & 0.28 region & \\
\hline & 0.48 region:h & ehold & 0.51 region:h & ehold \\
\hline \multirow[t]{2}{*}{ ICC } & $0.12_{\text {region }}$ & & 0.09 region & \\
\hline & 0.38 region:h & ehold & 0.38 region:h & ehold \\
\hline observations (region/household/individual) & $38 / 3,808 / 8$ & & & \\
\hline Bayes $\mathrm{R}^{2}$ & 0.39 & & 0.42 & \\
\hline
\end{tabular}

Note. ${ }^{*} 95 \%$ highest density interval does not contain 0.

While in the case of titulars the analysis by an ethnic group might potentially give more insights into these relationships, our data enforce an aggregated approach. This is due to the relatively small sizes of individual non-Russian ethnic groups in the sample and the fact that most of them are to be wholly categorized as holding either the majority or minority status. A comparison of attitudes of members of a particular titular ethnic group depending on whether their group holds a majority or minority status in their region of residence is plausible only for Tatars. Such an analysis shows that negative attitudes toward southern immigrants among majority Tatars (i.e., Tatars in Tatarstan, 
$\mathrm{M}=3.18, \mathrm{SD}=0.91$ ) were lower than among minority Tatars (Tatars outside of Tatarstan, $\mathrm{M}=$ $3.56, \mathrm{SD}=1.02)$. The Bayes factor in favor of a difference was substantial, $\mathrm{BF}_{10}=5.05$. In the case of negative attitudes toward western immigrants, the difference between majority Tatars $(M=2.94$, $\mathrm{SD}=0.95)$ and minority Tatars $\left(\mathrm{M}=3.02, \mathrm{SD}=1.08\right.$ ) was not supported, $\mathrm{BF}_{10}=0.18$ (which indicates substantial evidence for no difference). These results are thus in line with our main findings.

\section{Discussion}

The study suggests that the relative position of an ethnic in-group in Russia is not equally important as a predictor of attitudes toward migrant out-groups across different origins. Group position proved to play a role in predicting attitudes toward migrants originating from the "south" (encompassing North and South Caucasus, Central Asia, and China, Vietnam, and Korea) but not toward migrants coming from the "west" (Ukraine and Moldova). Namely, an ethnic in-group's majority status is positively (for ethnic Russians) and negatively (for titulars) related to exclusionist attitudes toward immigrants only in the case of the southern origins. This finding suggests that the mechanisms underlying attitudes might differ between the two clusters of migrant out-groups. These results run contrary to the results obtained by Gorodzeisky (2019), who argued that those who perceive their collective as vulnerable tend to show exclusionary attitudes toward all foreigners regardless of their origin. This discrepancy may be explained by her focus on attitudes toward immigration (admitting foreigners at all) rather than attitudes toward immigrants (who may already be present in the country). It may also be explained by her focus on collective vulnerability in the socioeconomic sphere, while the relative position of an in-group as expressed by the majorityminority status may refer to competition over both material and symbolic resources. Besides, as we argue, social distance with regard to potential migrant neighbors-by which we capture antiimmigrant attitudes in our paper-is more likely linked to symbolic than economic considerations. This reassures us that we should seek explanations for the differences in attitudes toward the two clusters of origins recorded in our study in the cultural rather than the socioeconomic realm.

While we were unable to empirically test the mechanisms behind the encountered associations due to data limitations, we can discuss possible explanations for differences between the two clusters of target groups that may be tested in future studies. In line with the differentiated threat approach, our result may be explained by the source of threat each out-group triggers. Ukrainian and Moldovan migrants are usually indistinguishable from the national majority group, that is, ethnic Russians, both in appearance and by virtue of their Russian language skills. Given the cultural differences between ethnic groups and the "invisible character" of the Ukrainian and Moldovan migrant minorities, we may assume that migrants of Ukrainian and Moldovan origin do not tend to trigger a symbolic threat among members of the receiving population. Referring to Minescu and Poppe (2011), the differing role of group position may be explained by differences in the level of threat evoked by an out-group and whether it is perceived as encroaching on the area of in-group privileges. Immigrants from Ukraine and Moldova are generally associated with lower levels of symbolic threat and less often with encroachment-inter alia, given their decreasing demographic potential and immigration trends as of 2008-2009 (the time when the survey was conducted). This would suggest that in-group position plays a role in predicting negative attitudes toward immigrants only with reference to out-groups that trigger high levels of symbolic threat and are associated with encroachment.

The interpretation referring to the source and level of threat seems plausible in the case of ethnic Russian respondents, for whom immigrants from Ukraine and Moldova presumably indeed pose no symbolic threat or pose a lower level of threat, contrary to newcomers from the remaining regions of origin. It seems, however, less relevant as an explanation for members of some non-Russian ethnic groups, given their cultural closeness to members of some other target groups. For instance, one would not necessarily expect high levels of symbolic threat evoked by newcomers 
from Central Asia among Tatars, since both groups are predominantly Muslim. This caveat was actually reflected in our results, since the evidence for the importance of group position in the case of Ukrainian and Moldovan migrants was stronger (nevertheless, not decisive) for titular than for ethnic Russian respondents (see figure 1 and figure A1).

An alternative and perhaps more universal explanation relates to the place in the ethnic hierarchy occupied by target out-groups. Previous research demonstrated that while people show an inclination to maintain status hierarchy between groups, natives prefer immigrant groups of higher status to those of lower status (Kustov 2019). Bessudnov (2016), in his study on public attitudes toward immigrants, concluded that the effect of immigrant concentration (which may be perceived as a measure of the relative size of an out-group) on attitudes toward immigrants appears to be stronger for groups positioned lower in the ethnic hierarchy. Our findings suggest that the effect of relative size of an in-group is also stronger for lower-positioned ethnic out-groups. While the compatibility of these findings may seem obvious in the context of a typical nation-state, where the relative size of an in-group directly (inversely) translates into the relative size of a migrant outgroup, it is not as obvious in the case of a multiethnic society, where additional groups other than an in-group and a migrant out-group are present.

Although cultural differences between an in-group and a specific out-group seem to be not without importance, perception of immigrants may also be influenced by the group cues in migration discourse-namely it may depend on the politicization of the presence (or inflow) of a particular group (Valentino, Brader, and Jardina 2013). Thus, the effects of group position may be conditional on whether a particular group is framed as threatening (or anxiety producing) by the media, politicians, and others (which did not happen for Ukrainian and Moldovan migrants in 2008-2009 contrary to immigrants of the remaining origins). It should be stressed here, however, that the political changes that took place in the last decade-involving the military conflict with Ukraine and the resultant inflow of Ukrainian citizens and anti-Ukrainian propaganda-might have influenced the way residents of Russia, in particular ethnic Russians, perceive immigrants originating from Ukraine.

Unfortunately, the survey analyzed in this paper did not directly measure the level and type of perceived threat associated with different migrant origins. We are also unable to discern whether the differences between the two clusters of migrant out-groups follow from the group threat or group status differentials (nor do we find these explanations incompatible). The inability to check the above presumptions based on the RLMS-HSE dataset is the main limitation of the study. Future research would benefit from deepening the existing knowledge on the source and level of threat evoked by different migrant groups in Russia and their relation to attitudes, particularly their potential moderating role for the association between the relative position of an ethnic in-group and attitudes. Another important limitation is the impossibility to reliably test the effect of majority status at the municipal (PSU) level with the RLMS-HSE data. Should the majority status be considered at the municipal level, there will only be one group in the sample that may be classified as majority titular (Kabardins in Zalukokoazhe and Zol'skii raion), and there will not be a sufficient number of ethnic Russians in a minority position to allow statistical inference and warrant generalizability of findings.

Despite these limitations, the present study advances our understanding of the relationship between the relative position of an ethnic in-group and attitudes toward immigrants, and of attitudes toward different immigrant targets in contemporary Russia. It extends earlier studies that focused on the role of in-group position in determining anti-immigrant attitudes in Russia by taking a closer look at these relations at the subnational rather than the national level and investigating the role of a majority status in a region as a determinant of attitudes toward a number of different migrant groups. This way it also contributes to the recently growing strand of literature suggesting that attitudes toward different immigrant groups may not only differ in terms of their magnitude but also be driven by different mechanisms. 
The theoretical implications discussed above point to the potential limitations of the model explaining attitudes toward out-groups with a relative position of an in-group. Namely, the results of the empirical analysis suggest that the source and the level of threat induced by out-groups, in addition to their position in the ethnic hierarchy, may potentially contribute to the differential operation of an in-group position between target groups. If there is no symbolic threat or there is a low level of threat involved, or a target group occupies a high position in the ethnic hierarchy, the mechanisms operating for the general category of immigrants-yielding a positive effect of majority status at a regional level on attitudes of ethnic Russians and a negative effect for members of titular ethnic groups-do not seem to work. This may be due to the fact that the conditions underlying prejudice according to the original model of Blumer-namely, those related to the sense of superiority regarding one's own group, a belief in its distinctiveness from the out-group, and perceived threat-are not fully met. One may even go a step further and state that, given high levels of acceptance reported toward Ukrainian and Moldovan migrants, it is not a prejudice that is explained here. ${ }^{8}$ Hence, it should come as no surprise that the group position model is not very useful in explaining attitudes toward them.

In the light of previous results obtained in relation to attitudes toward the general category of immigrants (cf. Brunarska 2019), the obtained findings suggest that when respondents in Russia answer a general question on attitudes toward immigrants, they tend to have immigrants of southern origin in mind. This is in line with Kustov's (2019) suggestion that people do not have groups of higher status in mind when thinking about a general category of immigrants. This also lends some credence to the presence of "imagined immigration" (Blinder 2015) and may indicate that the in-group position predicts attitudes only in relation to out-groups that are featured in the imagined immigration construct. Our findings also resonate with Ruedin's (2020) argument that studies based on questions on attitudes toward immigrants in the generic sense likely capture the right correlates, but they may miss important nuances, such as variability across different origins.

When attempting to generalize the results to other contexts, such as the European one, an important question occurs: whether the mechanism implied for national minority in-groups works only for autochthonous (or sedentary) ethnic in-groups or whether it is also capable of explaining the role of relative in-group size in the case of ethnic in-groups that are mostly composed of immigrants or of a broader category of people with immigrant backgrounds (e.g., secondgeneration migrants). While we are not able to answer this question in the Russian context, where none of the non-Russian, non-titular ethnic groups hold a majority status at a regional level, the growing diversity of Western societies may soon provide an appropriate setting to test the usefulness of the model in relation to relatively newly arrived in-groups in various subnational locations.

Acknowledgments. Earlier versions of the paper were presented at: the Open Seminar of the Center for Research on Prejudice at the University of Warsaw, Poland, in June 2018; the Wisconsin Russia Project Young Scholars Conference, held at the University of Wisconsin-Madison, US, in July 2018; and the Polish Sociological Congress, held in Wrocław, Poland, in September 2019. We would like to express thanks to the participants of these events as well as to Saja Toruńczyk-Ruiz, Agata Górny, Ania Janicka, Aneta Piekut and anonymous reviewers for their constructive comments.

Disclosures. None.

\section{Notes}

1 By seeking the causes of prejudice in different threat profiles, differentiated threat approach resembles the sociofunctional threat-based approach to prejudice (Cottrell and Neuberg 2005), which posits that specific threats evoked by different groups entail different emotional reactions.

2 The specific ethnic groups named in parentheses were listed in the survey questionnaire. Inclusion of North Caucasian ethnic groups is symptomatic. It points to the extension of an anti-immigrant frame to internal migrants in Russia (Markowitz and Peshkova 2016). 
3 Both majority titulars in our sample (Tatars, Chuvashes, and Kabardins in their ethnic republics) and minority titulars (encompassing primarily Tatars outside of Tatarstan, Udmurts, Komis, Balkars, Mordvinians, Chuvashes outside of Chuvashia, and Bashkirs) are composed of both Turkic and non-Turkic, and predominantly Muslim and non-Muslim ethnic groups. Hence, cultural differences do not fully overlap with ethnic groups' demographic concentration (numerical dominance).

4 Bayesian methods in contrast to frequentist methods do not rely on asymptotics (e.g., Stegmueller 2013). Therefore, we found the former approach better suited to our complex study design, with a small number of individuals within each household $(\mathrm{N}=2.21$ on average). While interpretation of results in Bayesian and frequentist approaches is similar, the Bayesian approach may be considered more intuitive. Instead of confidence intervals, the Bayesian approach uses credible intervals or highest posterior density intervals (HPDI). In the case of linear models, the differences between credible intervals and HPDI are subtle, and thus the choice of one of them is usually a matter of preference. The Bayesian intervals identify regions where finding a parameter value is $\mathrm{X} \%$ probable, whereas confidence interval is a range of values designed to include the true value of the parameter $\mathrm{X}$ times in a series of 100 experiments. In more general terms, while the frequentist approach treats parameters as fixed and data as random-resulting from an infinite number of trials, the Bayesian approach treats data as given and parameters as uncertain, and thus describes parameters with statistical distributions (rather than a single true value).

5 See also figure A1 in the appendix for the results of an analysis for the six immigrant groups disaggregated.

6 Assuming that the mechanism driving anti-immigrant attitudes may differ among nonmigrants and people with a migration background, we additionally run the analysis for a subsample of nonmigrants $(\mathrm{N}=7,206$, instead of $\mathrm{N}=8,094)$. While the values of contrast parameters were smaller, the overall pattern and thus the substantive conclusions remained the same. Among ethnic Russians, those holding majority status had more negative attitudes toward southern immigrants than ethnic Russians in minority position in their regions of residence, $\psi=0.14,95 \%$ HPDI $[0.02,0.26]$. Among titulars, in turn, those holding majority status within a region had on average less negative attitudes toward southern immigrant groups than titulars in minority position in their regions of residence, $\psi=-0.13,95 \%$ HPDI $[-0.24,-0.01]$. In the case of attitudes toward western immigrants, such pattern of results was not observed. Among ethnic Russians there was no credible difference between those holding majority vs. minority status, $\psi=0.04,95 \%$ HPDI $[-0.06,0.14]$, and similarly among titulars no credible difference was observed, $\psi=-0.04$, 95\% HPDI $[-0.13,0.06]$.

7 To check whether it is indeed the majority and not the titular status within a region that matters for anti-immigrant attitudes, we recalculated the model for a dominant administrative status within a region instead of a majority status within a region. We call it a "dominant administrative status within a region" instead of "titular status within a region" because we also test its effect for ethnic Russians (in their case a dominant administrative status means that no ethnic group holds a titular status in their region of residence; i.e., they reside in a territorially defined federal subject). In the case of both targets of attitudes-southern and western immigrant groups-there was no credible interaction of ethnic group type (Russians vs. titulars) and the dominant administrative status within a region, for southern groups $\psi=-0.03$, 95\% HPDI $[-0.10,0.02]$ and for western groups $\psi=-0.03,95 \%$ HPDI $[-0.09,0.03]$. Furthermore, in the case of both target groups, there were also no main effects of dominant administrative status within a region, for southern immigrants $\psi=0.08,95 \%$ HPDI $[-0.03,0.20]$, and for western immigrants $\psi=0.01,95 \%$ HPDI $[-0.10,0.12]$. Hence, we conclude that it is the majority rather than the dominant administrative status within a region that is a meaningful predictor of attitudes toward immigrants of southern origin. 
8 Cf. Raijman, Hochman, and Davidov (2021), who found a negative effect of perceived threat on opposition to Jewish immigrants in Israel, motivating it with the argument that they are seen as an asset rather than as a threat.

\section{References}

Alexseev, Mikhail. 2010. “Majority and Minority Xenophobia in Russia: The Importance of Being Titulars." Post-Soviet Affairs 26 (2): 89-120.

Alexseev, Mikhail. 2011. "Societal Security, the Security Dilemma, and Extreme Anti-Migrant Hostility in Russia." Journal of Peace Research 48 (4): 509-523.

Bahry, Donna. 2016. “Opposition to Immigration, Economic Insecurity and Individual Values: Evidence from Russia." EuropeAsia Studies 68 (5): 893-916.

Bergh, Robin, and Nazar Akrami. 2016. "Generalized Prejudice: Old Wisdom and New Perspectives.” In The Cambridge Handbook of the Psychology of Prejudice, edited by Chris Sibley and Fiona Barlow, 438-460. Cambridge: Cambridge University Press.

Bessudnov, Alexey. 2016. "Ethnic Hierarchy and Public Attitudes towards Immigrants in Russia.” European Sociological Review 32 (5): 1-14.

Bessudnov, Alexey, and Andrey Shcherbak. 2020. "Ethnic Discrimination in Multi-Ethnic Societies: Evidence from Russia." European Sociological Review 36 (1): 104-120.

Blinder, Scott. 2015. "Imagined Immigration: The Impact of Different Meanings of 'Immigrants' in Public Opinion and Policy Debates in Britain." Political Studies 63 (1): 80-100.

Bloom, Pazit Ben-Nun, Gizem Arikan, and Gallya Lahav. 2015. "The Effect of Perceived Cultural and Material Threats on Ethnic Preferences in Immigration Attitudes.” Ethnic and Racial Studies 38 (10): 1760-1778.

Blumer, Herbert. 1958. "Race Prejudice as a Sense of Group Position.” Pacific Sociological Review 1 (1): 3-7.

Bobo, Lawrence, and Vincent Hutchings. 1996. "Perceptions of Racial Group Competition: Extending Blumer's Theory of Group Position to a Multiracial Social Context.” American Sociological Review 61 (6): 951-972.

Bogardus, Emory. 1925. “Measuring Social Distance.” Journal of Applied Sociology 9:299-308.

Brader, Ted, Nicholas Valentino, and Elizabeth Suhay. 2008. "What Triggers Public Opposition to Immigration? Anxiety, Group Cues, and Immigration Threat.” American Journal of Political Science 52 (4): 959-978.

Brunarska, Zuzanna. 2019. “Anti-Immigrant Attitudes in Russia: The Group Position Model Reconsidered." Europe-Asia Studies 71 (9): 1508-1531.

Bürkner, Paul-Christian. 2017. "Brms: An R Package for Bayesian Multilevel Models Using Stan.” Journal of Statistical Software 80 (1): 1-28.

Butkovich Kraus,Nicole, and Yoshiko Herrera. 2010. "Xenophobia and Nationalism in Russia: A Multilevel Analysis of Xenophobia and Its Relationship to Nationalism." Paper presented at the annual meeting of the American Political Science Association, Washington, DC, September 2-5.

Carle, Adam. 2009. "Fitting Multilevel Models in Complex Survey Data with Design Weights: Recommendations." BMC Medical Research Methodology 9 (49): 1-13.

Cottrell, Catherine, and Steven Neuberg. 2005. "Different Emotional Reactions to Different Groups: A Sociofunctional ThreatBased Approach to 'Prejudice.” Journal of Personality and Social Psychology 88 (5): 770-789.

Enders, Craig. 2010. Applied Missing Data Analysis. New York: Guilford Press.

Ford, Robert. 2011. "Acceptable and Unacceptable Immigrants: How Opposition to Immigration in Britain Is Affected by Migrants' Region of Origin.” Journal of Ethnic and Migration Studies 37 (7): 1017-1037.

Ford, Robert, and Jonathan Mellon. 2020. "The Skills Premium and the Ethnic Premium: A Cross-National Experiment on European Attitudes to Immigrants." Journal of Ethnic and Migration Studies 46 (3): 512-532.

Gabry, Jonah, Daniel Simpson, Aki Vehtari, Michael Betancourt, and Andrew Gelman. 2019. "Visualization in Bayesian Workflow." Journal of the Royal Statistical Society A 182 (2): 389-402.

Gelman, Andrew, Aleks Jakulin, Maria Grazia Pittau, and Yu-Sung Su. 2008. “A Weakly Informative Default Prior Distribution for Logistic and Other Regression Models.” Annals of Applied Statistics 2 (4): 1360-1383.

Gerber, Theodore P. 2014. "Beyond Putin? Nationalism and Xenophobia in Russian Public Opinion." The Washington Quarterly 37 (3): 113-134.

Gerber, Theodore P., and Jane Zavisca. 2020. "Experiences in Russia of Kyrgyz and Ukrainian Labor Migrants: Ethnic Hierarchies, Geopolitical Remittances, and the Relevance of Migration Theory." Post-Soviet Affairs 36 (1): 61-82.

Gorodzeisky, Anastasia. 2019. "Opposition to Immigration in Contemporary Russia." Post-Soviet Affairs 35 (3): $205-222$.

Gorodzeisky, Anastasia, and Anya Glikman. 2018. "Two Peoples - Two Stories: Anti-Immigrant Attitudes in Post-Socialist Russia." Social Problems 65 (4): 543-563.

Gorodzeisky, Anastasia, Anya Glikman, and Dina Maskileyson. 2015. “The Nature of Anti-Immigrant Sentiment in PostSocialist Russia." Post-Soviet Affairs 31 (2): 115-135.

Gorodzeisky, Anastasia, and Moshe Semyonov. 2019. "Unwelcome Immigrants: Sources of Opposition to Different Immigrant Groups among Europeans.” Frontiers in Sociology 4 (24): 1-10. 
Grigor'ev, Dmitrii. 2017. “Diskriminatsiia migrantov v sotsioekonomicheskoi sfere: Rol' mezhgruppovykh ustanovok prinimaiushchego naseleniia." Sotsial'naia psikhologiia i obshchestvo 8 (3): 63-84.

Grigoryan, Lusine. 2016. "National Identity and Anti-Immigrant Attitudes: The Case of Russia." In Dynamics of National Identity: Media and Societal Factors of What We Are, edited by Jürgen Grimm, Leonie Huddy, Peter Schmidt, and Josef Seethaler, 206-228. New York: Routledge.

Gudkov, Lev. 2005. “Smeshchennaia agressiia: Otnoshenie Rossiian k migrantam.” Vestnik obshchestvennogo mneniia 6 (80): 60-77.

Hagendoorn, Louk. 1995. "Intergroup Biases in Multiple Group Systems: The Perception of Ethnic Hierarchies." European Review of Social Psychology 6 (1): 199-228.

Hagendoorn, Louk, Rian Drogendijk, Sergey Tumanov, and Joseph Hraba. 1998. "Inter-Ethnic Preferences and Ethnic Hierarchies in the Former Soviet Union." International Journal of Intercultural Relations 22 (4): 483-503.

Hainmueller, Jens, and Daniel Hopkins. 2015. "The Hidden American Immigration Consensus: A Conjoint Analysis of Attitudes toward Immigrants." American Journal of Political Science 59 (3): 529-548.

Harell, Allison, Stuart Soroka, Shanto Iyengar, and Nicholas Valentino. 2012. "The Impact of Economic and Cultural Cues on Support for Immigration in Canada and the United States." Canadian Journal of Political Science / Revue canadienne de science politique 45 (3): 499-530.

Hellwig, Timothy, and Abdulkader Sinno. 2017. "Different Groups, Different Threats: Public Attitudes towards Immigrants." Journal of Ethnic and Migration Studies 43 (3): 339-358.

Herrera, Yoshiko, and Nicole Butkovich Kraus. 2016. "Pride versus Prejudice Ethnicity, National Identity, and Xenophobia in Russia." Comparative Politics 48 (3): 293-315.

Hraba, Joseph, Carolyn S. Dunham, Sergey Tumanov, and Louk Hagendoorn. 1997. "Prejudice in the Former Soviet Union." Ethnic and Racial Studies 20 (3): 613-627.

Jeffreys, Harold. 1961. The Theory of Probability. 3rd ed. Oxford: Clarendon Press.

Konitzer, Tobias, Shanto Iyengar, Nicholas Valentino, Stuart Soroka, and Raymond Duch. 2019. "Ethnocentrism versus GroupSpecific Stereotyping in Immigration Opinion: Cross-National Evidence on the Distinctiveness of Immigrant Groups." Journal of Ethnic and Migration Studies 45 (7): 1051-1074.

Kustov, Alexander. 2019. "Is There a Backlash Against Immigration from Richer Countries? International Hierarchy and the Limits of Group Threat.” Political Psychology 40 (5): 973-1000.

Laruelle, Marlène. 2010. “The Ideological Shift on the Russian Radical Right.” Problems of Post-Communism 57 (6): 19-31.

Levada. 2018. Obshchestvennoe mnenie - 2017. Moscow: Yuri Levada Analytical Center.

Markowitz, Lawrence P., and Vera Peshkova. 2016. “Anti-Immigrant Mobilization in Russia’s Regions: Local Movements and Framing Processes.” Post-Soviet Affairs 32 (3): 272-298.

Martinovic, Borja, and Maykel Verkuyten. 2013. “'We Were Here First, so We Determine the Rules of the Game': Autochthony and Prejudice towards out-Groups.” European Journal of Social Psychology 43 (7): 637-647.

Meuleman, Bart, Koen Abts, Koen Slootmaeckers, and Cecil Meeusen. 2018. "Differentiated Threat and the Genesis of Prejudice: Group-Specific Antecedents of Homonegativity, Islamophobia, Anti-Semitism, and Anti-Immigrant Attitudes." Social Problems 66: 222-244.

Minescu, Anca, and Edwin Poppe. 2011. "Intergroup Conflict in Russia.” Social Psychology Quarterly 74 (2): 166-191.

Pipiia, Karina. 2017. "Struktura obraza migranta v rossiiskom obshchestvennom mnenii." Vestnik obshchestvennogo mneniia 1-2 (124): 130-140.

Popova, Irina, and Valentina Osipova. 2013. “Otnoshenie prinimaiushchei storony k migrantam.” Vestnik obshchestvennogo mneniia 1 (114): 81-88.

Pratto, Felicia, Jim Sidanius, Lisa M. Stallworth, and Bertram F. Malle. 1994. "Social Dominance Orientation: A Personality Variable Predicting Social and Political Attitudes.” Journal of Personality and Social Psychology 67 (4): 741-763.

Raijman, Rebeca, Oshrat Hochman, and Eldad Davidov. 2021. "Ethnic Majority Attitudes toward Jewish and Non-Jewish Migrants in Israel: The Role of Perceptions of Threat, Collective Vulnerability, and Human Values." Journal of Immigrant \& Refugee Studies. Published online ahead of print February 22, 2021. doi: 10.1080/15562948.2021.1889107.

RLMS-HSE. 2008. Russia Longitudinal Monitoring Survey of the Higher School of Economics. National Research University Higher School of Economics; ZAO Demoscope; Carolina Population Center, University of North Carolina at Chapel Hill; Institute of Sociology Russian Academy of Sciences. www.cpc.unc.edu/projects/rlms-hse, www.hse.ru/org/hse/rlms. (Accessed December 1, 2016.)

Rosstat. 2013. Russian 2010 Population Census Data. www.gks.ru/free_doc/new_site/perepis2010/croc/perepis_itogi1612.htm. (Accessed February 2, 2017.)

Ruedin, Didier. 2020. “Do We Need Multiple Questions to Capture Feeling Threatened by Immigrants?” Political Research Exchange 2 (1).

Schoon, Eric, and Kathryn Freeman Anderson. 2017. "Rethinking the Boundaries: Competitive Threat and the Asymmetric Salience of Race/Ethnicity in Attitudes toward Immigrants." Socius: Sociological Research for a Dynamic World 3:1-14.

Stegmueller, Daniel. 2013. "How Many Countries for Multilevel Modeling? A Comparison of Frequentist and Bayesian Approaches." American Journal of Political Science 57 (3): 748-761.

Stephan, Walter, Oscar Ybarra, and Kimberly Rios Morrison. 2009. "Intergroup Threat Theory." In Handbook of Prejudice, Stereotyping, and Discrimination, edited by Todd Nelson, 43-59. New York: Psychology Press. 
Tartakovsky, Eugene, and Sophie Walsh. 2020. “Are Some Immigrants More Equal than Others? Applying a Threat-Benefit Model to Understanding the Appraisal of Different Immigrant Groups by the Local Population." Journal of Ethnic and Migration Studies 46 (19): 3955-3973.

Timberlake, Jeffrey, Junia Howell, Amy Baumann Grau, and Rhys Williams. 2015. "Who "They" Are Matters: Immigrant Stereotypes and Assessments of the Impact of Immigration.” Sociological Quarterly 56 (2): 267-299.

Turper, Sedef, Shanto Iyengar, Kees Aarts, and Minna van Gerven. 2015. "Who Is Less Welcome? The Impact of Individuating Cues on Attitudes towards Immigrants.” Journal of Ethnic and Migration Studies 41 (2): 239-259.

Valentino, Nicholas, Ted Brader, and Ashley Jardina. 2013. "Immigration Opposition Among U.S. Whites: General Ethnocentrism or Media Priming of Attitudes About Latinos?” Political Psychology 34 (2): 149-166.

van Buuren, Stef, and Karin Groothuis-Oudshoorn. 2011. "Mice: Multivariate Imputation by Chained Equations in R.” Journal of Statistical Software 45 (3): 1-67.

Velasco González, Karina, Maykel Verkuyten, Jeroen Weesie, and Edwin Poppe. 2008. "Prejudice towards Muslims in the Netherlands: Testing Integrated Threat Theory." British Journal of Social Psychology 47 (4): 667-685.

World Data on Education 2010/11. 2012. Geneva: United Nations Educational, Scientific and Cultural Organization, International Bureau of Education.

Zick, Andreas, Carina Wolf, Beate Küpper, Eldad Davidov, Peter Schmidt, and Wilhelm Heitmeyer. 2008. "The Syndrome of Group-Focused Enmity: The Interrelation of Prejudices Tested with Multiple Cross-Sectional and Panel Data." Journal of Social Issues 64 (2): 363-383.

\section{Appendix}

Table A1. Descriptive Statistics, Weighted Data

\begin{tabular}{|c|c|c|c|}
\hline Variable & Range & $M(S D)$ or $\%$ & $\%$ missing \\
\hline attitudes (Ukraine) & $1-5$ & $2.75(1.00)$ & 3.60 \\
\hline attitudes (Moldova) & $1-5$ & $2.89(0.98)$ & 4.58 \\
\hline attitudes (North Caucasus) & $1-5$ & $3.54(1.05)$ & 4.20 \\
\hline attitudes (South Caucasus) & $1-5$ & $3.53(1.05)$ & 4.16 \\
\hline attitudes (Central Asia) & $1-5$ & $3.52(1.06)$ & 4.45 \\
\hline attitudes (China, Vietnam, Korea) & $1-5$ & $3.65(1.06)$ & 5.71 \\
\hline group status/ethnicity - majority Russians & $0 / 1$ & $84 \%$ & 6.59 \\
\hline group status/ethnicity - majority titulars & $0 / 1$ & $5 \%$ & 6.59 \\
\hline group status/ethnicity - minority Russians & $0 / 1$ & $3 \%$ & 6.59 \\
\hline group status/ethnicity - minority titulars & $0 / 1$ & $4 \%$ & 6.59 \\
\hline group status/ethnicity - others & $0 / 1$ & $4 \%$ & 6.59 \\
\hline age & $18-96$ & $45.7(18.3)$ & 0 \\
\hline gender $($ female $=0$, male $=1$ ) & $0 / 1$ & $44 \%$ & 0 \\
\hline years of education* & $0-25$ & $12.5(3.11)$ & 0.16 \\
\hline born abroad (no=0, yes $=1$ ) & $0 / 1$ & $8 \%$ & 3.1 \\
\hline income & $0-574,000$ & $9,185(12,671)$ & 6.04 \\
\hline locality - town & $0 / 1$ & $26 \%$ & 0 \\
\hline locality - urban type settlement & $0 / 1$ & $6 \%$ & 0 \\
\hline locality - village & $0 / 1$ & $26 \%$ & 0 \\
\hline
\end{tabular}

*Calculated from education level referring to World Data on Education 2010/11 (2012).

Source: calculations based on RLMS-HSE (2008) 


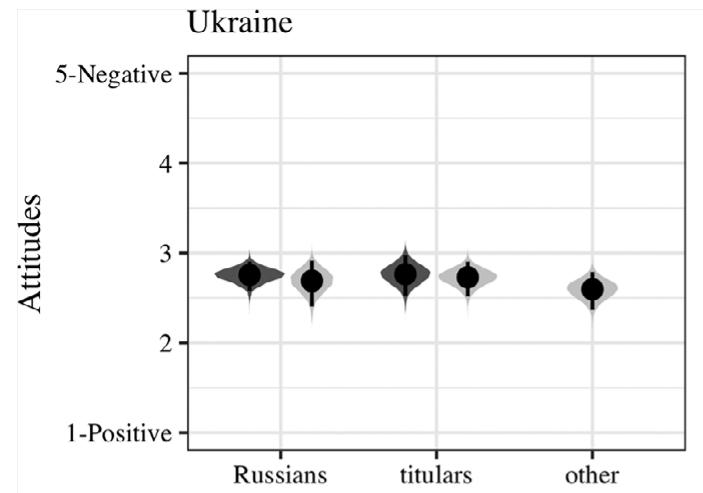

North Caucasus

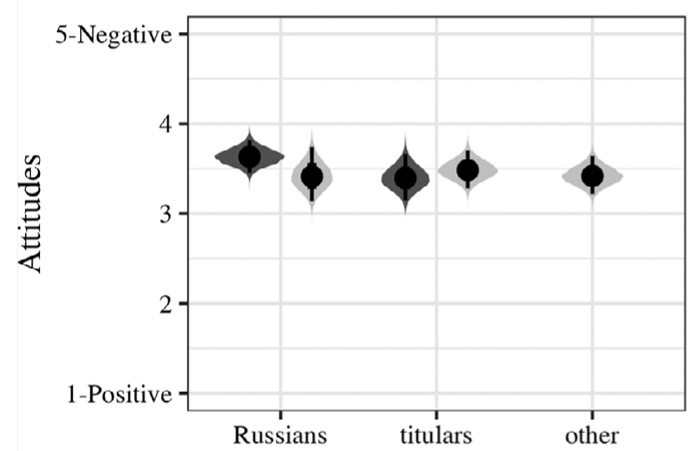

Central Asia

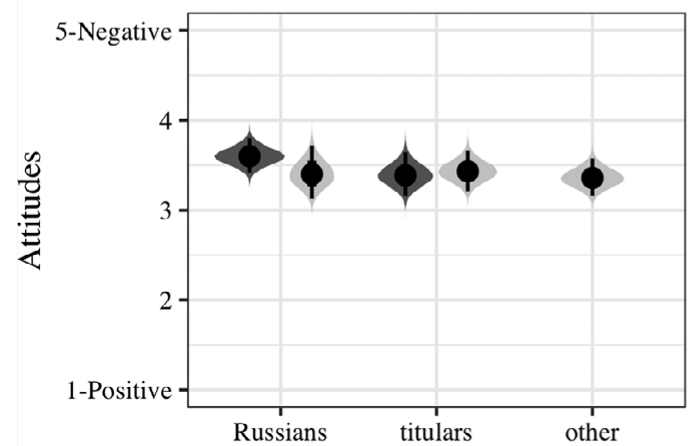

Status of ethnic ingroup:

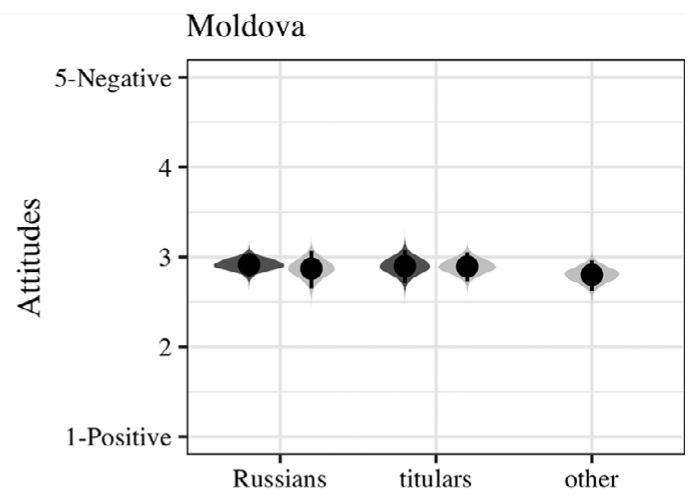

South Caucasus

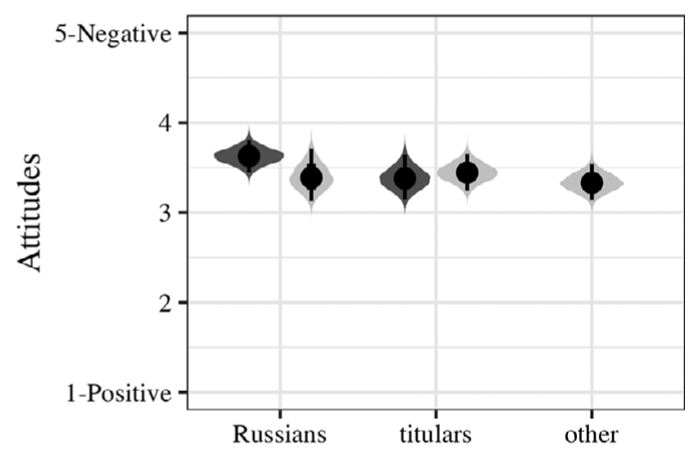

China, Vietnam, and Korea

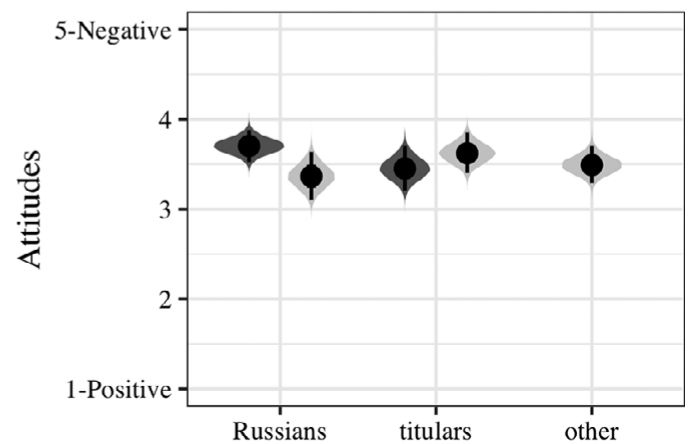

majority minority

Figure A1. Average Attitudes toward Immigrants of the Six Origins among Ethnic Russians, Titulars, or Other Ethnic Groups, Qualified by Majority versus Minority Status. Estimated Means are Adjusted for Covariates: Gender, Age, Years of Education, Income, Migration Status, Locality Type, and Clustering.

Cite this article: Brunarska, Z. and Soral, W. 2022. Does Origin Matter? Ethnic Group Position and Attitudes Toward Immigrants: The Case of Russia. Nationalities Papers 50: 219-236, doi:10.1017/nps.2021.71 